\title{
PENGARUH PEMBERIAN PUPUK NPK MUTIARA TERHADAP PERTUMBUHAN DAN PRODUKSI TANAMAN JAGUNG (Zea Mayz L.) DI DESA BATU BOY KEC. NAMLEA KAB. BURU
}

\author{
Said AR. Assagaf * \\ Staf Pengajar Prodi Agroteknologi Fapertahut Universitas Iqra Buru \\ Email : saidabdurahmanasegaf@gmail.com
}

\begin{abstract}
ABSTRAK
Penelitian ini bertujuan untuk mengetahui Pemberian Pupuk NPK Mutiara berbagai takaran pada Pertumbuhan Jagung ( Zea Mayz. L). Penelitian ini dengan menggunakan Rancangan Acak Kelompok ( RAK ) satu faktor, dosis NPK Mutira yang terdiri dari 6 taraf perlakuan, yaitu P0 $=$ Kontrol (tanpa perlakuan), P1 =100 $\mathrm{Kg} /$ ha setara $60 \mathrm{~g} /$ petak, P2 = $150 \mathrm{Kg} /$ ha setara $90 \mathrm{~g} /$ petak, P3 = $200 \mathrm{Kg} /$ ha setara 120 g/petak, P4 = $250 \mathrm{Kg} /$ ha setara $150 \mathrm{~g} /$ petak, $\mathrm{P} 5=300 \mathrm{Kg} /$ ha setara $180 \mathrm{~g} /$ petak. Hasil penelitian menunjukan bahwa pemberian NPK Mutiara 180 gram/petak memberikan nilai rata-rata tertinggi pada pengamatan tanaman tinggi tanaman $192,72 \mathrm{~cm}$ jumlah daun 15,65 helai panjang tongkol tanpa klobot $17,16 \mathrm{~cm}$ diameter tongkol tanpa klobot 3,46 cm bobot 100 biji 33,42 gram serta produksi biji kering 6,03 (ton/ha)..
\end{abstract}

Keyword : Zea Mayz, Produksi Jagung, NPK Mutiara

\section{PENDAHULUAN}

\subsection{Latar Belakang}

Tanaman jagung termasuk komoditas unggulan agrobisnis karena memiliki potensi multiguna antara lain penghasil bahan pangan, pakan ternak, dan bahan baku berbabagai industri. Pengenalan dan pemahaman prospek pengembangan budi daya tanaman jagung skalah komersial sangat penting dalam upaya menerapakan teknologi, produksi dan pascapanen untuk meningkatkan pendapatan kesejahteraan petani (Rukmana, 2007).

Upaya pemenuhan kebutuhan jagung dalam negeri ditingkatan dengan pendekatan Perluasan Areal Tanam (PAT) atau Sasaran produksi jagung tahun 2016 sebesar 24.000 .000 ton pipilan kering (PK), sedangkan pencapaian produksi jagung tahun 2015 hanya sebesar 19.833.289 ton pipilan kering (PK). Salah satu upaya yang dilakukan ialah dengan perluasan areal jagung satu juta hektar di Kabupaten Buru, Provinsi Maluku dengan sasaran produksi jagung sebesar 20,31 juta ton. ( Dirjen Tanaman Pangan, 2016 ).

Peningkatan luasan areal tanam perlu dibarengi dengan perbaikan teknik budidaya agar produktivitas juga meningkat.
Pemupukan dilakukan sebagai upaya untuk mencukupi kebutuhan tanaman agar tujuan produksi dapat dicapai. Hal ini mengingat tanaman jagung sangat memerlukan suplai unsur hara yang cukup. Pemupukan sangat mendukung upaya melestarikan produktivitas lahan dan menjaga ketersediaan unsur hara dalam tanah.

Pupuk NPK Mutiara merupakan pupuk majemuk yang mengandung unsur hara $\mathbf{N}$ (16\%) dalam bentuk NH3, P(16\%) dalam bentuk PO5 dan K(16\%) dalam bentuk (K2O).Unsur Nitrogen $(\mathrm{N})$ diperlukan untuk pembentukan karbohidrat, protein, lemak dan persenyawaan organik lainnya dan unsur Nitrogen memegang peranan penting sebagai penyusun klorofil yang menjadikan daun berwarna hijau. Unsur fosfor (P) yang berperan penting dalam transfer energi di dalam sel tanaman, mendorong perkembangan akar dan pembuahan lebih awal, memperkuat batang sehingga tidak mudah rebah, serta meningkatkan serapan pada awal pertumbuhan. Unsur kalium (K) juga sangat berperan dalam pertumbuhan tanaman misalnya untuk memacu translokasi karbohidrat dari daun keorgan tanaman (Aguslina, 2009). 
Respon tanaman terhadap pemupukan tergantung pada jenis tanah, faktor lingkungan lainnya maupun dari jenis varietas yang digunakan. Hal ini berarti bahwa jenis dan dosis pupuk yang akan diaplikasikan harus sesuai jenis tanah dan jenis tanaman yang akan ditanam. Kenyataannya bahwa, aplikasi pupuk yang dilakukan oleh petani biasanya berdasarkan pada rekomendasi umum. Konsekuensinya bahwa hasil tanaman akan tinggi jika kondisi tanah dan respon varietas yang digunakan positif maka hasilnya akan tinggi, demikian pula sebaliknya. Oleh karena itu, dalam upaya untuk meningkatkan produksi tanaman jagung khususnya varietasdengan menggunkan pupuk NPK Mutiara dirasa perlu dilakukan kajian untuk mengetahui mengetahui respon tanaman jagung varietas terhadap dosis pupuk NPK Mutiara.

\subsection{Tujuan dan Manfaat Penelitian}

Penelitian ini bertujan untuk mengkaji respon tanaman jagung terhadap aplikasi pupuk NPK Mutiara dengan dosis yang berbeda. Penelitian ini diharapkan dapat bermanfaat sebagai bahan informasi dan referensi pembanding untuk penelitian lanjutan tentang pemanfaatan pupuk NPK Mutiara dalam pertanaman jagung di lahan kering.

\section{METODOLOGI PENELITIAN}

\subsection{Tempat dan Waktu}

Penelitian ini dilaksanakan di Desa Batu Boy, Kecamatan Namlea, Kabupaten Buru. Berlangsung daribulan Maret sampai dengan Juli 2018

\subsection{Bahan dan Alat}

Bahan yang digunakan pada penelitian ini terdiri dari Benih Jagung dan Pupuk NPK Mutiara.

Alat yang di gunakan adalah parang, sabit, cangkul,meter,tali plastik/tali rafia, timbangan, ember, hand sparayer, alat tulis dan kamera.

\subsection{Rancangan Percobaaan}

Penelitian ini dengan menggunakan Rancangan Acak Kelompok (RAK) satu faktor, dosis NPK Mutira yang terdiri dari 6 taraf perlakuan, yaitu : $\mathrm{P0}=$ Kontrol (tanpa perlakuan), P1 = $100 \mathrm{Kg} /$ ha setara 60 g/petak, P2 $=150 \mathrm{Kg} / \mathrm{ha}$ setara $90 \mathrm{~g} /$ petak, $\mathrm{P} 3=200 \mathrm{Kg} / \mathrm{ha}$ setara $120 \mathrm{~g} /$ petak, $P 4=250 \mathrm{Kg} / \mathrm{ha}$ setara 150 $\mathrm{g} /$ petak dan P5 = $300 \mathrm{Kg} /$ ha setara $180 \mathrm{~g} /$ petak

\subsection{Parameter Tanaman}

Adapun parameter yang diamati adalah sebagai berikut :

1. Tinggi tanaman $(\mathrm{cm})$, diperoleh dengan cara mengukur jarak dari pangkal batang yang telah diberi tanda sampai ke ujung daun tertinggi dengan menggunakan meter atau penggaris. Pengukuran mulai dilakukan pada saat tanaman jagung berumur 2 minggu setelah tanam dan selanjutnya dilakukan dengan interval 2 minggu sekali sampai tanaman memasuki fase generatif atau mengeluarkan bunga.

2. Jumlah daun (helai), diperoleh dengan cara menghitung jumlah daun yang terbentuk sempurna dan segar. Perhitungan mulai dilakukan pada saat tanaman jagung berumur 2 minggu setelah tanam dan selanjutnya dilakukan dengan interval 2 minggu sekali sampai tanaman memasuki fase generatif atau mengeluarkan bunga.

3. Panjang tongkol tanpa kelobot (cm), diperoleh dengan mengukur jarak dari pangkal tongkol hingga ujung tongkol yang telah dibuka kelobotnya menggunakan meteran atau penggaris. Pengukuran dilakukan pada masingmasing tongkol pada setiap tanaman sampel setelah panen.

4. Diameter tongkol tanpa klobot $(\mathrm{cm})$, diperoleh dengan mengukur diameter tongkol yang telah dibuka kelobotnya menggunakan kaliper (jangka sorong) pada bagian tengah. Pengukuran dilakukan pada masing-masing tongkol pada setiap tanaman sampel setelah panen.

5. Bobot pipilan 100 biji kering perpetak (g), diperoleh dengan menimbang 100 biji jagung yang telah dikeringkan. Penimbangan dilakukan menggunakan timbangan analitik. 
6. Bobot produksi kering per hektar (Ton ha1), di peroleh dengan menimbang berat pipilan dari seluruh tanaman tiap petak, dengan disertakan kemudian dikonversikan ke hektar.

\subsection{Analisis data}

Data yang diperoleh dianalisis secara statistik menggunakan analisis ragam (ansira) dan jika menunjukan pengaruh nyata atau sangat nyata maka di lanjutkan dengan uji beda nilai jujur ( BNJ ) untuk melihat perbedaan antar perlakuan ( Harafiah, 2009)

\section{HASIL DAN PEMBAHASAN}

\subsection{Hasil}

Peningkatan pertumbuhan jagung melalui pemberian pupuk merupakan usaha untuk memperbaiki kondisi pertumbuhan jagung dan menambah keseburan tanah. Pemberian pupuk NPK Mutiara pada pertumbuhan jagung dapat dilihat melalui indikator pertumbuhan antara lain, tinggi tanaman, jumlah daun, panjang tongkol, diameter tongkol tanpa klobot, berat pipilan 100 biji perpetak dan berat produksi Ton per Hektar. Rata-rata pengaruh pupuk NPK Mutiara pada pertumbuhan tanaman jagung.

3.1.1. Rekapitulasi Sidik Ragam Pengaruh Dosis Pupuk NPK Mutiara.

Rekapitulasi Sidik Ragam Pengaruh Dosis Pupuk NPK Mutiara Terhadap Pertumbuhan dan Hasil Tanaman Jagung dapat dilihat pada Tabel 1.

3.1.2. Tinggi Tanaman Jagung.

Berdasarkan hasil Uji BNJ (Beda Nyata

Jujur) pada Tabel 2 menunjukanbahwa perlakuan NPK Mutiara P5 (180 gr/petak) diperoleh bahwa rata-rata pertumbuhan tinggi tanaman jagung bervariasi. Pertumbuhan tinggi tanaman jagung memberika nilai rata-rata pada 14 HST sebesar 40,84 cm, 28 HST sebesar 106,16 cm dan 42 HST sebesar 196,72 $\mathrm{cm}$ berbeda sangat nyata dengan P0 (konrol), P1 (60 gr/petak), P2 (90 gr/petak), P3 (120 gr/petak)sedangkan dengan perlakuan P4 (150 gr/petak) tidak berbeda nyata.

Tabel 1. Rekapitulasi Sidik Ragam Pengaruh Dosis Pupuk NPK Mutiara

\begin{tabular}{llcc}
\hline No & Parameter pengamatan & Kelompok & Perlakuan \\
\hline 1 & Tinggi tanaman & & \\
& $-\quad 14 \mathrm{hst}$ & $* *$ & $* *$ \\
& $-\quad 28 \mathrm{hst}$ & tn & $* *$ \\
\hline 2 & $-\quad 42 \mathrm{hst}$ & & \\
& Jumlah daun & $* *$ & tn \\
& $-\quad 14 \mathrm{hst}$ & tn & $* *$ \\
& $-\quad 28 \mathrm{hst}$ & tn & $* *$ \\
\hline 3 & Panjang tongkol tanpa klobot & $* *$ & $*$ \\
\hline 4 & Diameter tongkol tanpa klobot & $* *$ & $* *$ \\
\hline 5 & Berat 100 biji gram & tn & $* *$ \\
\hline 6 & Berat biji ton/ha & tn & $* *$ \\
\hline
\end{tabular}

Tabel 2. Rata-Rata Pertumbuhan Tinggi Tanaman Selama Pengamatan

\begin{tabular}{cccc}
\hline \multirow{2}{*}{ Perlakuan } & \multicolumn{3}{c}{ Rataan Tinggi Tanaman Jagung } \\
\cline { 2 - 4 } & 14 HST & 28 HST & 42 HST \\
\hline P0 & $36,09 \mathrm{a}$ & $78,13 \mathrm{a}$ & $176,25 \mathrm{a}$ \\
P1 & $38,03 \mathrm{a}$ & $94,63 \mathrm{a}$ & $192,00 \mathrm{a}$ \\
P2 & $38,18 \mathrm{~b}$ & $96,03 \mathrm{a}$ & $192,56 \mathrm{a}$ \\
P3 & $38,78 \mathrm{~b}$ & $98,28 \mathrm{~b}$ & $193,59 \mathrm{~b}$ \\
P4 & $39,09 \mathrm{c}$ & $98,81 \mathrm{c}$ & $194,16 \mathrm{~b}$ \\
P5 & $40,84 \mathrm{c}$ & $106,16 \mathrm{c}$ & $196,72 \mathrm{~d}$ \\
\hline BNJ (0,05) & 3,85 & 3,94 & 5,04 \\
\hline
\end{tabular}

Keterangan : Angka-angka yang diikuti oleh huruf yang berbeda nyata berarti berbeda nyata pada taraf uji BNJ $(0,05)$ 


\subsubsection{Jumlah Daun Tanaman Jagung.}

Produksi/Hasil (Tabel 3.) Berdasarkan hasil Uji BNJ (Beda Nyata Jujur) pada tabel 2 menunjukanbahwa perlakuan NPK Mutiara P5 (180 gr/petak) diperoleh bahwa rata-rata pertumbuhan jumlah daun tanaman jagung bervariasi. Pertumbuhan jumlah dauntanaman jagung memberika nilai rata-rata pada 14 HST sebesar 6,44 helai, 28 HST sebesar 11,03 helai dan 42 HST sebesar 15,65 helaiberbeda sangat nyata dengan P3 (120 gr/petak), P2 (90 gr/petak), P1 (60 gr/petak), dan P0 (control)sedangkan dengan perlakuan P4 (150 gr/petak) dan P5 (180 gr/petak) tidak berbeda nyata.

Tabel 3. Rata-Rata Pertumbuhan Jumlah Daun Tanaman Selama Pengamatan

\begin{tabular}{cccc}
\hline \multirow{2}{*}{ Perlakuan } & \multicolumn{3}{c}{ Rataan Jumlah DaunTanaman Jagung } \\
\cline { 2 - 4 } & $14 \mathrm{HST}$ & $28 \mathrm{HST}$ & $42 \mathrm{HST}$ \\
\hline P0 & $5,94 \mathrm{a}$ & $9,56 \mathrm{a}$ & $14,34 \mathrm{a}$ \\
P1 & $6,00 \mathrm{a}$ & $10,34 \mathrm{a}$ & $14,46 \mathrm{~b}$ \\
P2 & $6,13 \mathrm{a}$ & $10,38 \mathrm{a}$ & $14,78 \mathrm{~b}$ \\
P3 & $6,19 \mathrm{~b}$ & $10,74 \mathrm{~b}$ & $15,06 \mathrm{~b}$ \\
P4 & $6,22 \mathrm{~b}$ & $10,94 \mathrm{~b}$ & $15,34 \mathrm{c}$ \\
P5 & $6,44 \mathrm{~b}$ & $11,03 \mathrm{c}$ & $15,65 \mathrm{~d}$ \\
\hline BNJ (0,05) & 1,92 & 1,37 & 1,88 \\
\hline
\end{tabular}

Keterangan : Angaka-angka yang diikuti oleh huruf yang berbeda nyata berarti berbeda nyata pada taraf uji BNJ $(0,05)$

\subsubsection{Hasil tanaman jagung.}

Berdasarkan hasil Uji BNJ (Beda Nyata Jujur) pada Tabel 4 menunjukanbahwa perlakuan NPK Mutiara P5 (180 gr/petak) memberikan nilai rata-rata pada panjang tongkol yaitu 17,66 cm berbeda sangat nyata dengan P0 (control) P1 (60 gr/petak)P2 (90 gr/petak)P3 (120 gr/petak sedangkan dengan perlakuan P4 (150 gr/petak) tidak berbeda nyata.
Berdasarkan hasil Uji BNJ (Beda Nyata Jujur) pada tabel 4 menunjukan bahwa perlakuan NPK Mutiara P5 (180 gr/petak) memberikan nilai rata-rata pada diameter tongkol yaitu $3,46 \mathrm{~cm}$ berbeda sangat nyata dengans P0 (control) P1 (60 gr/petak),P2 (90 gr/petak), sedangkan dengan perlakuan P3 (120 gr/petak) dan P4 (150 gr/petak) tidak berbeda nyata.

Tabel 4. Rata-Rata Panjang tongkol tanpa klobot, diameter tongkol tanpa klobot, berat 100 biji, berat produksi (ton/ha)

\begin{tabular}{ccccc}
\hline \multirow{2}{*}{ Perlakuan } & \multicolumn{4}{c}{ Rata-rata pengamatan } \\
\cline { 2 - 5 } & $\begin{array}{c}\text { Panjang tongkol } \\
\text { tanpa klobot }\end{array}$ & $\begin{array}{c}\text { Diameter tongkol } \\
\text { tanpa klobot }\end{array}$ & $\begin{array}{c}\text { Berat 100 biji } \\
\text { (gram) }\end{array}$ & $\begin{array}{c}\text { Berat produksi } \\
\text { (ton/ha }\end{array}$ \\
\hline P0 & $15,38 \mathrm{a}$ & $2,59 \mathrm{a}$ & $26,57 \mathrm{a}$ & $2,41 \mathrm{a}$ \\
P1 & $15,97 \mathrm{~b}$ & $2,72 \mathrm{a}$ & $26,99 \mathrm{~b}$ & $2,75 \mathrm{a}$ \\
P2 & $16,22 \mathrm{~b}$ & $2,83 \mathrm{~b}$ & $27,11 \mathrm{c}$ & $3,10 \mathrm{a}$ \\
P3 & $16,50 \mathrm{c}$ & $3,23 \mathrm{c}$ & $27,43 \mathrm{bc}$ & $3,38 \mathrm{~b}$ \\
P4 & $17,44 \mathrm{c}$ & $3,28 \mathrm{c}$ & $29,89 \mathrm{cb}$ & $4,38 \mathrm{~b}$ \\
P5 & $17,66 \mathrm{~d}$ & $3,26 \mathrm{~d}$ & $33,42 \mathrm{~d}$ & $6,03 \mathrm{c}$ \\
\hline BNJ (0,05) & 2,15 & 1,69 & 1,97 & 1,50 \\
\hline
\end{tabular}

Keterangan : Angaka-angka yang diikuti oleh huruf yang berbeda nyata berarti berbeda nyata pada taraf uji BNJ $(0,05)$

Berdasarkan hasil Uji BNJ (Beda Nyata Jujur) pada tabel 4 menunjukanbahwa perlakuan NPK Mutiara P5 (180 gr/petak) memberikan nilai rata-rata pada berat 100 biji 
yaitu 33,42 gram berbeda sangat nyata dengan P0 (control) P1 (60 gr/petak)dan P4 (150 gr/petak) sedangkan dengan perlakuan P2 (90 gr/petak)P3 (120 gr/petak) tidak berbeda nyata.

Berdasarkan hasil Uji BNJ (Beda Nyata Jujur) pada tabel 4 menunjukan bahwa perlakuan NPK Mutiara P5 (180 gr/petak) memberikan nilai rata-rata pada96 HST untuk berat biji yaitu 6,03 Ton/Ha berbeda sangat nyata dengan P0 (control) P1 (60 gr/petak) dan P4 (150 gr/petak) sedangkan dengan perlakuan P2 (90 gr/petak)P3 (120 gr/petak) tidak berbeda nyata.

\subsection{Pembahasan}

Berdasarkan hasil Uji BNJ (Beda Nyata Jujur) pada table 1 menunjukan bahwa perlakuan NPK Mutiara P5 (180 gr/petak) diperoleh bahwa rata-rata pertumbuhan tinggi tanaman jagung bervariasi. Pertumbuhan tinggi tanaman jagung memberikan nilai rata-rata pada 14 HST sebesar $40,84 \mathrm{~cm}, 28$ HST sebesar $106,16 \mathrm{~cm}$ dan 42 HST sebesar $196,72 \mathrm{~cm}$ berbeda sangat nyata dengan P0 (konrol), P1 (60 gr/petak), P2 (90 gr/petak), P3 (120 gr/petak) sedangkan dengan perlakuan P4 (150 gr/petak) tidak berbeda nyata. Hal ini disebabkan kebutuhan tanaman masih memanfaatkan unsur hara yang tersedia di dalam tanah. Dengan adanya peningkatan dosis pupuk NPK Mutiara Semakin meningkat dosis pupuk, maka terjadi kenaikan pertumbuhan tinggi tanaman, oleh karena itu bahwa dengan semakin dewasanya tanaman, maka sistim perakaran telah berkembang dengan baik dan lengkap, sehingga tanaman semakin mampu menyerap unsur hara dalam bentuk anion dan kation yang mengandung unsur $\mathrm{N}, \mathrm{P}$ dan $\mathrm{K}$ yang terdapat pada pupuk Mutiara tersebut. Dengan banyaknya unsur hara yang dapat diserap oleh tanaman, maka pertumbuhan dan perkembangan tanaman semakin meningkat.(Mulyani, 2008).

Berdasarkan hasil Uji BNJ (Beda Nyata Jujur) pada tabel 2 menunjukan bahwa perlakuan NPK Mutiara P5 (180 gr/petak) diperoleh bahwa rata-rata pertumbuhan jumlah daun tanaman jagung bervariasi. Pertumbuhan jumlah daun tanaman jagung memberika nilai rata-rata pada $14 \mathrm{HST}$ sebesar 6,44 helai, $28 \mathrm{HST}$ sebesar 11,03 helai dan 42 HST sebesar 15,65 helaiberbeda sangat nyata dengan P3 (120 gr/petak), P2 (90 gr/petak), P1 (60 gr/petak), dan P0 (control)sedangkan dengan perlakuan P4 (150 gr/petak) dan P5 (180 gr/petak) tidak berbeda nyata. Hal ini di sebabkan karena dalam penyerapan unsur nitrogen pengaruhnya untuk pembetukan protein yang di butuhkan dalam pembetukan daun dan ranting. Pada perlakuan P5 sudah dianggap cukup untuk proses pertumbuhan pada tanaman jagung dalam pembetukan daun. Sedangkan pada perlakuan P0 sudah dianggap cukup dalam penyerapan unsur nitrogen, tetapi belum maksimal dalam proses pembetukan daun pada tanaman jagung

(Mulyani, 2007).

Berdasarkan hasil Uji BNJ (Beda Nyata Jujur) pada tabel 3 menunjukan bahwa perlakuan NPK Mutiara P5 (180 gr/petak) memberikan nilai rata-rata pada panjang tongkol yaitu $17,66 \mathrm{~cm}$ berbeda sangat nyata dengan P0 (control) P1 (60 gr/petak)P2 (90 gr/petak)P3 (120 gr/petak sedangkan dengan perlakuan P4 (150 gr/petak) tidak berbeda nyata.Hal ini mungkindisebabkan oleh pemberian pupuk unsur phospor mampumenyuplai ketersediaan unsur hara untuk proses pembetukan buah. Sehingga pemberian pupuk P5 menghasilkanpersentase kontribusi tertinggi dan dapat berpengaruh terhadap tongkol jagung. (Rukmana,2007)

Berdasarkan hasil Uji BNJ (Beda Nyata Jujur) pada tabel 3 menunjukan bahwa perlakuan NPK Mutiara P5 (180 gr/petak) memberikan nilai rata-rata pada diameter tongkol yaitu $3,46 \mathrm{~cm}$ berbeda sangat nyata dengan P0 (control) P1 (60 gr/petak),P2 (90 gr/petak), sedangkan dengan perlakuan P3 (120 gr/petak) dan P4 (150 gr/petak) tidak berbeda nyata.

Berdasarkan hasil Uji BNJ (Beda Nyata Jujur) pada tabel 3 menunjukan bahwa perlakuan NPK Mutiara P5 (180 gr/petak) memberikan nilai rata-rata pada HST untuk berat 100 biji yaitu 33,42 gram berbeda sangat nyata dengan P0 (control) P1 (60 gr/petak)dan P4 (150 gr/petak) sedangkan dengan perlakuan P2 (90 gr/petak)P3 (120 gr/petak) tidak berbeda nyata.

Berdasarkan hasil Uji BNJ (Beda Nyata Jujur) pada tabel 3 menunjukan bahwa 
perlakuan NPK Mutiara P5 (180 gr/petak) memberikan nilai rata-rata padaberat biji yaitu 6,03 Ton/Ha berbeda sangat nyata dengan P0 (control) P1 (60 gr/petak)dan P4 (150 gr/petak) sedangkan dengan perlakuan P2 $(90$ gr/petak)P3 (120 gr/petak) tidak berbeda nyata. Tanaman yang tinggi serta daun yang banyak ternyata tidak harus memberikan hasil jagung manis tertinggi seperti panjang tongkol tanpa klobot, diameter tongkol tanpa klobot dan bobot 100 gram. Pada penelitian ini, selain faktor ketersediaan hara yang mempengaruhi tinggi tanaman diduga dipengaruh oleh lingkungan tumbuh tanaman jagung seperti sinar matahari dalam hal ini cahaya. Diketahui bahwa pertumbuhan, perkembangan dan produksi suatu tanaman ditentukan oleh dua faktor utama yaitu faktor genetik dan faktor lingkungan. Cahaya dan tersedianya unsurunsur hara yang cukup di dalam tanah merupakan faktor lingkungan yang sangat mempengaruhi pertumbuhan dan hasil tanaman. Cahaya matahari sangat menentukan proses fotosintesis. Fotosintesis adalah proses dasar pada tumbuhan untuk menghasilkan makanan. Makanan yang dihasilkan akan menentukan ketersediaan energi untuk pertumbuhan dan perkembangan tumbuhan. Cahaya merupakan faktor penting terhadap berlangsungnya fotosintesis, sementara fotosintesis merupakan proses yang menjadi kunci dapat berlangsungnya proses metabolisme yang lain di dalam tanaman. kekurangan cahaya akan menimbulkan gejala etiolasi, dimana batang tanaman akan tumbuh lebih cepat namun lemah dan daunnya berukuran kecil, tipis dan berwarna pucat (tidak hijau). Walaupun kebutuhan hara cukup tetapi penerimaan cahaya matahari tidak optimal maka pertumbuhan tanaman akan terganggu.(Widyanto, 2012).

\section{PENUTUP}

Pemberian NPK Mutiara 180 gram/petak memberikan nilai rata-rata tertinggi pada pengamatan tanaman tinggi tanaman $192,72 \mathrm{~cm}$ jumlah daun 15,65 helai panjang tongkol tanpa klobot $17,16 \mathrm{~cm}$ diameter tongkol tanpa klobot $3,46 \mathrm{~cm}$ bobot 100 biji 33,42 gram serta produksi biji kering 6,03 (ton/ha). Disarankan untuk pembudidaya tanaman jagung apabila menggunakan pupuk NPK Mutiara dengan dosis 180 gram/petak, karena penelitian ini menunjukan bahwa penggunaan pupuk NPK Mutiara dengan dosis tersebut memberikan hasil produksi terbaik yaitu 6,03 ton. Namun demikian masih perlu dilaksanakan penelitian lebih lanjut tentang bagaimana kombinasi yang tepat antara pengguna pupuk NPK Mutiara dengan faktor lain yang sesuai agar produksi tanaman jagung meningkat.

\section{DAFTAR PUSTAKA}

Anonim. 2008. Petunjuk Pemupukan. AgroMedia. Jakarta

Anonim, 2015. Data Produksi Tanaman Pangan Kabupaten Buru, Dinas Pertanian Kabupaten Buru, Namlea.

Anonim, 2015. Data Produksi, Luas Lahan, Luas Panen Tanaman Jagung, Dinas Pertanian Propinsi Maluku, Ambon.

Anonim, 2016. Pentunjuk Teknis Gerakan Pengembangan Jagung Hibrida.Direktorat Jendral Tanaman Pangan dan Kementrian Pertanian. Jakarta.

Departemen Pertanian. 2005. Prospek dan Arah Pengembangan Agribisnis Jagung. Badan Penelitian dan Pengembangan Pertanian.

Doni. 2008. Pengaruh Dosis dan Waktu Pemberian Pupuk N dan K Terhadap Pertumbuhan dan Produksi Jagung Manis.Jakarta. 
Departemen Pertanian. 2016. Badan Pusat Statistik dan Direktorat JenderalTanaman Pangan. Maluku.

Hafsa. M. J, 2004. Peningkatan Produksi Dan Mutu Jagung. Peran Strategis Mekanisasi Pertanian Dalam Pengembangan Agroindustri Jagung. Jakarta.

Hanafiah. K.A, 2009. Rancangan Percobaan.PT. Grafindo Persada. Jakarta.

http://jagung-hibrida.blogspot.co.id/2009/11/budidaya-jagung.html.

Hardjadi,S. S. 2007.Pengantar Agronomi. Gramedia. Jakarta.

Mashudi, 2007. Bercocok Tanam Palawija. Azka Mulia Media, Jakarta.

Hermanto, 2005. Jagung. Teknologi Produksi dan Pascapanen. Pusat Penelitian dan Pengembangan Tanaman Pangan.Bogor.

Kresnatita S. 2004. Pengaruh Pemberian Pupuk Organik dan Nitrogen terhadap Pertumbuhan dan Hasil Tanaman Jagung Manis. Mahasiswa Program Pasca Sarjana. Malang.

Marsono dan P. Sigit. 2001. Pupuk Akar. 96 hlm.Penebar Swadaya. Jakarta.

http://dasar-pertanian.blogspot.co.id/2016/08/manfaat-pupuk-npk-mutiara-untuk-tanaman.html (http://pupuklopedia.blogspot.com/2014/07/pupuk-npk-mutiara.html).

Mulyani Sutedjo, M. 2008. Pupuk Dan Cara Pemupukan. Rineka Cipta. Jakarta.

Rukmana Rahmat, dan Yudirachman Herdi, 2007. Budi Daya, Pascapanen dan Penganekaragaman. Aneka Ilmu Jakarta. 